\title{
The Effect of Acidosis on Albumin Level in Patients Treated With Regular Hemodialysis (Single Center Study)
}

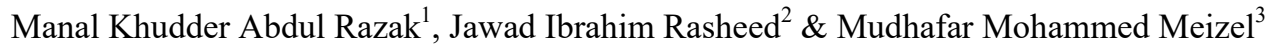 \\ ${ }^{1}$ Department of Medicine, Baghdad College of Medicine, University of Baghdad, Baghdad, Iraq \\ ${ }^{2}$ Council of Arab Board of Nephrology, Baghdad, Iraq \\ ${ }^{3}$ Department of Medicine, College of Medicine, University of Al Qadisiyah, Iraq \\ Correspondence: Manal Khudder Abdul Razak, Faculty member, Department of Medicine, Baghdad College of \\ Medicine, University of Baghdad, Bab al- Muadham Campus, Baghdad, Iraq. Tel: 964-770-267-9678. E-mail: \\ manaladhadh@gmail.com
}

Received: August 1, 2018 Accepted: September 24, 2018 Online Published: October 13, 2018

doi:10.5539/gjhs.v10n11p57 URL: https://doi.org/10.5539/gjhs.v10n11p57

\begin{abstract}
Background: Hypoalbuminemia is the most powerful predictor of mortality in end-stage renal disease on hemodialysis. Metabolic acidosis induces net negative nitrogen and total body protein balance. Some patients undergoing maintenance dialysis have low plasma bicarbonate levels due to inadequate dialysis. We aimed to evaluate the role of metabolic acidosis on serum albumin concentration in patients with end stage renal disease on hemodialysis, and to determine differences of serum bicarbonate level before and after hemodialysis in actual situation.
\end{abstract}

Methods: This cross sectional comparative study was conducted in the Iraqi Center for Hemodialysis/ Baghdad Teaching Hospital from June to December 2015. It included 100 subjects with end stage renal disease on hemodialysis. They were divided equally into cases with low albumin and comparison group with normal albumin level. Serum bicarbonate and the Kt/V were measured for all subjects before, after, and before next hemodialysis session to show the adequacy of dialysis.

Results: There was a significant association between low bicarbonate and low albumin level in hemodialysis patient and between numbers and duration of dialysis session with albumin. Low Kt/V was significantly associated with hypoalbuminemia. There was no statistically significant association between age and gender with hypoalbuminemia.

Conclusion: This study shows that patients with metabolic acidosis had a lower serum albumin concentration and there was a significant correlation between numbers, duration and adequacy of hemodialysis sessions and albumin level. We recommend to increase the numbers of dialysis centers in Iraq and adjust the bicarbonate doses in dialysate according to patient's bicarbonate levels.

Keywords: acidosis, serum albumin, hemodialysis

\section{Introduction}

Malnutrition affects $1 / 3$ of hemodialysis (HD) patients and associates with a higher risk of morbidity and mortality. Serum albumin (S. Alb) is a marker of nutrition and inflammation, and hypoalbuminemia is the most powerful predictor of death in patients with ESRD (Yashpal \& Kher, 2012).

One of the most powerful regulators of albumin synthesis is availability of dietary protein. Protein calorie malnutrition is clearly a potential cause of reduced albumin synthesis, decreased plasma albumin levels and increased morbidity and mortality in the chronically ill population (Gama-Axelsson et al., 2012). Malnutrition is not the only cause of hypoalbuminemia in this population; otherwise nutritional supplementation should effectively restore albumin pools as it does in patients with hypoalbuminemia caused by protein malnutrition (National Kidney Foundation [NKF-DOQI], 2002).

In addition to being nutritionally modulated, albumin is also a negative acute-phase reactive protein (The Royal College of Pathologists of Australasia [RCPA] Manual, Jun 3, 2015). It is possible that some albumin might be lost across the dialysis membrane in patients on HD, contributing to hypoalbuminemia in them (Kapl, Halley, Lance, \& 
Graeber, 1995). Metabolic acidosis (MA) is commonly associated with chronic kidney disease (CKD) (Căpuşă et al., 2017). With worsening renal function, progressive MA and acidemia can develop (Pourafshar, Pourafshar, \& Soleimani, 2018). The prevalence of a serum bicarbonate (S. HCO3) concentration of $<22 \mathrm{meq} / \mathrm{L}$, for example, is $<5$ percent in CKD stages 1 and 2 and increases to approximately 25 percent in patients with CKD stage 5 (Kovesdy, 2012).

It is believed that the adequacy of dialysis can reduce mortality, increase longevity, and improve the quality-of-life in patients undergoing hemodialysis (Kalender \& Tosun, 2014). Effectiveness and adequacy of dialysis depend on many factors including type of filter, dialysis pump rate, dialysis time and speed, the application of high-flux dialyzer, blood flow rate, patient education, diet, and underlying diseases (Saeedi, Zareie, \& Javaheri, 2015).

There are five potential mechanisms by which MA contributes to nutritional abnormalities of patients with chronic renal failure (CRF):

- Acidosis is associated with proteolysis, and correction of this acidosis leads to a decrease in protein breakdown in both healthy humans and individuals with CRF. MA may also engender negative nitrogen balance (Carrero et al., 2013).

- Catabolic effects of MA that is mediated by two key mechanisms: First is increased activity of branched-chain ketoacid dehydrogenase (BCKAD) (Pickering et al., 2002) and second is increased activity of the ATP-dependent ubiquitin-proteasome pathway. In a recent study, (Zha \& Qian, 2017) demonstrated that an increase in serum total $\mathrm{CO}_{2}$ was associated with a significant reduction in the muscle content of ubiquitin mRNA as compared to healthy control patients.

- Increases in the $\mathrm{pH}$ of the medium even above normal physiologic $\mathrm{pH}$, were associated with progressively higher rates of protein synthesis (Rezende, Brandão de Souza, Modesto Pereira, \& Lugon, 2017).

- Insulin resistance is a known complication of CRF. Evidence suggests that this may in part be secondary to MA. Indeed, correction of MA in non-dialyzed patients with CRF enhances insulin-stimulated glucose uptake. Incubation of peritoneal macrophages in an acidic cell culture medium results in an increased production of tumor necrosis factor suggesting a possible link between MA and the inflammatory cascade (Lecker, Goldberg, \& Mitch, 2006).

One of the goals of dialysis therapy is to correct the MA. Dialysis therapies, as practiced today, are unable to completely correct MA in a substantial proportion of patients undergoing maintenance hemodialysis (MHD). Moreover, the serum bicarbonate levels in patients undergoing MHD follow a "saw-tooth pattern," with the lowest bicarbonate levels in the immediate pre-dialysis period (Kalntar-Zadeh, 2016).

Due to the importance of adequacy of dialysis in patients undergoing hemodialysis, evaluating the effectiveness and adequacy of dialysis help policymakers and healthcare professionals to revise their current practice toward more effective dialysis.

The relationship between correction of MA and serum albumin level, as well as the optimal dosage of oral bicarbonate required to maintain $\mathrm{S}$. $\mathrm{HCO} 3$ level within the physiological range has not been studied in the $\mathrm{CKD}$ population who are on MHD who are registered in the Iraqi Center for Hemodialysis.

In this present study; we aimed to evaluate the role of MA on S. Alb concentration in patients with ESRD on HD, and to determine differences of S. HCO3 level before and after HD in actual situation.

\section{Patients and Methods}

\subsection{Study Design \& Subjects}

This is a hospital-based cross-sectional study conducted at Dialysis Center of Baghdad Teaching Hospital in Medical City/Iraq from June 2015 to December 2015; to measure the risk of low S. $\mathrm{HCO}_{3}$ and low KT/V on S. albumin level.

We divided the study sample into two groups according to serum albumin level: Cases with $\mathrm{S}$. albumin concentrations at time of study below $3.5 \mathrm{~g} / \mathrm{dl}$ and comparison cases with S. albumin between 3.5-5.5 g/dl. (Both groups are patients with ESRD and on regular HD)

(KT/V is a number used to quantify HD treatment adequacy, $\mathrm{K}$ - dialyzer clearance of urea, $\mathrm{t}$ - dialysis time, $\mathrm{V}$ volume of distribution of urea, approximately equal to patient's total body water) (NKF-DOQI, 2015)

A total of 100 ESRD patients on regular HD were included; 50 patients as cases and 50 patients as comparison group (duration of HD ranges between 3months to 4 years). 


\subsection{Data Collection}

After taking consents from all participants, demographic data were taken regarding name, age, gender, underlying disease for $\mathrm{CKD}$, numbers of sessions of $\mathrm{HD}$, duration of each session, and duration of dialysis. S. Alb concentration was monthly measured in all patients $(\mathrm{N}=100)$.

$\mathrm{Kt} / \mathrm{V}$ was directly measured from the HD machine at the end of the session. Venous blood gas analysis for each participant was done before and after the HD session and before next session of HD.

The dialysis prescription was similar for all participants in this study, which was as follow:

Intermittent conventional HD by B- Braun Dialysis machine 2-3 times/week, 3-4 hours/ session. Low-flux polysulfone hollow fiber dialyzers. Temperature $36.5^{\circ} \mathrm{C}$. HCO3 level was $31.6 \mathrm{mmol} / 1 . \mathrm{Na}^{+}$was $145 \mathrm{mmol} / \mathrm{l}$ with normal profile. $\mathrm{K}^{+}=2 \mathrm{mmol} / \mathrm{l}, \mathrm{Ca}^{++}=1.5 \mathrm{mmol} / \mathrm{l}$.

Ultrafiltration was according to patient's need. Blood flow according to patient's need and types of vascular access. Dialysate flow was $500 \mathrm{ml} / \mathrm{min}$.

\subsection{Inclusion Criteria}

All patients with ESRD who undergo regular HD 2-3 sessions/ week; 3-4 hours for each session; at Dialysis Center in Baghdad Teaching Hospital.

\subsection{Exclusion Criteria}

The exclusion criteria were all patients with suspected hypoalbuminemia due to underlying pathology:

1). Chronic liver disease or liver cirrhosis.

2). Nephrotic syndrome with active disease.

3). Protein losing enteropathy like inflammatory bowel disease.

4). Neoplasia, severe systemic illness and diabetes mellitus.

\subsection{Measurements}

Serum $\mathrm{HCO} 3$ was measured by taking a venous blood sample from central vein to a syringe contained heparin and put it in ice bucket and send them within about 25 minutes to the respiratory care center in Baghdad Teaching Hospital where the blood gas analysis done by special device (ABL800FLEX). A venous $\mathrm{HCO} 3$ ranges between 22-26 mmol/l was considered as normal (Byrne et al., 2014).

Serum Albumin was measured for study group on HD program in same laboratory in the same HD center; by spectrophotometry method by added $1 \mathrm{ml}$ of test to 51 of serum with 5-minute wait at $37 \mathrm{c}$ using RANDOX kit. A value of 3.5-5.5 g/dl was considered as normal (Pathology Harmony Group, 2013).

$\mathrm{Kt} / \mathrm{V}$ was measured directly during HD session by (B- Braun HD machine) by monitoring the UV light absorbance at selected wave length correspond to dialysate concentration of uric acid or other small molecule weight solute and the ratio of early and late dialysate UV absorption mirror pre-and post- serum uric acid. Normal Kt/V $=1.2$. (Daugirdas, Blake, \& Ing, 2015).

\subsection{Statistical Analysis}

Statistical analysis was carried out using SPSS version 20. Continuous variables were presented as mean \pm standard deviation. Categorical variables were presented as frequencies and percentages. Independent sample t-test was used to compare between two continuous variables. Pearson's chi square $\left(\chi^{2}\right)$ test and fisher exact test were used to find the association between the categorical variables. A P- value of $\leq 0.05$ was considered as statistically significant. Logistic regression model was used for both groups of patients with ESRD.

\section{Results}

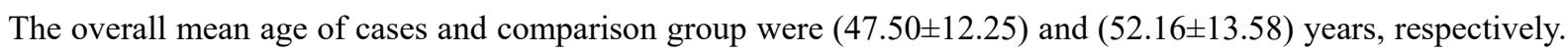
There was no significant mean difference of age between cases and comparison group $(\mathrm{t}=1.801, \mathrm{df}=98, \mathrm{P}$ - value $=$ 0.075). There was no significant difference between study groups by gender with $P$ - value $=0.15$ (Figure 1 ). 


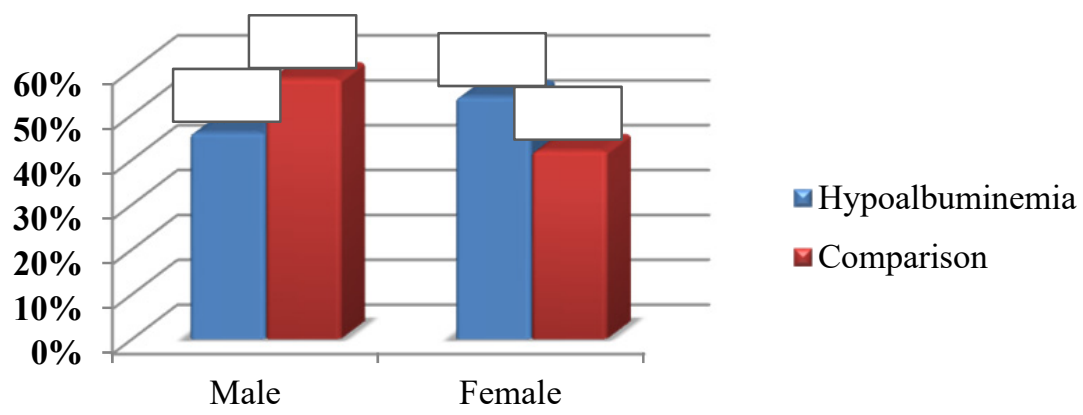

Figure 1. Difference of study groups by gender

There was a statistically significant association with HD sessions and duration between study groups. Cases were 9.33 and 18.86 times more likely to have two sessions of HD for four hours' duration, respectively (Table 1).

Table 1. Comparison of study groups by number and duration of hemodialysis sessions according to time of sessions

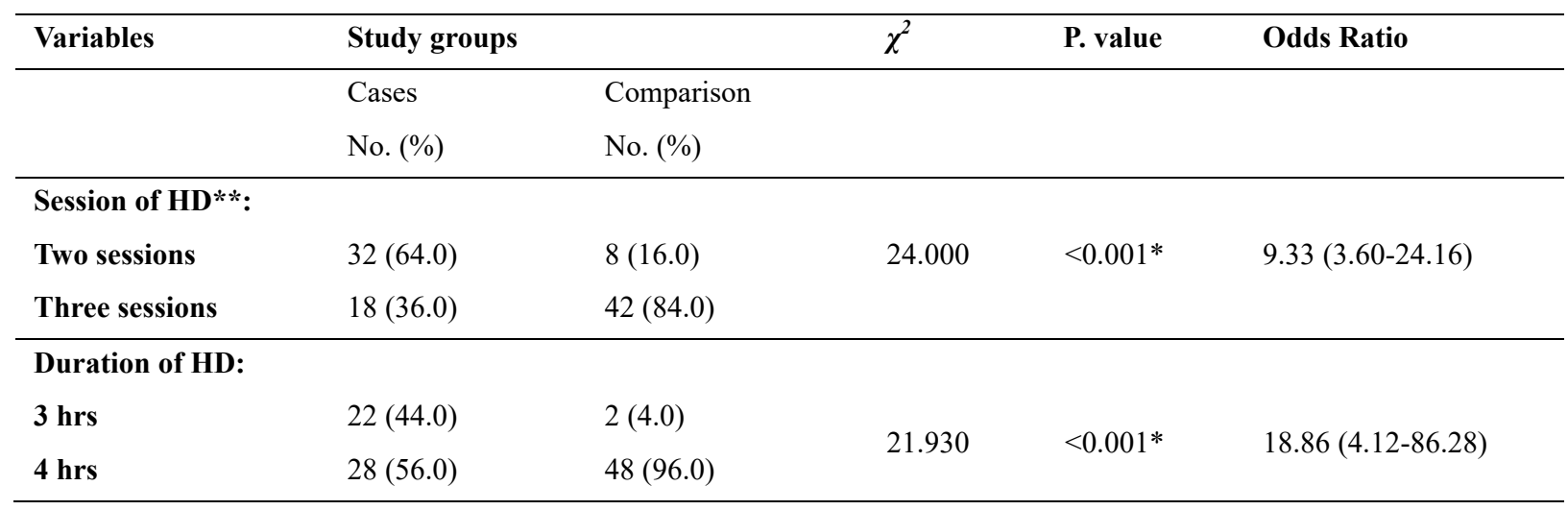

$* \mathrm{P}$ - value $\leq 0.05$ is significant, ** Hemodialysis.

There were significant differences between study groups by HCO3 according to time of measurement regarding HD sessions. Cases were 66 and 18.86 times more likely to have low HCO3 before HD sessions and before the next session, respectively. Meanwhile, Cases were 6 times more likely to have low HCO3 after HD sessions directly (Table 2$)$.

Table 2. Comparison of study groups by serum $\mathrm{HCO} 3$ level according to time of hemodialysis session

\begin{tabular}{|c|c|c|c|c|c|}
\hline \multirow{3}{*}{ Variable } & \multicolumn{2}{|c|}{ Study groups } & \multirow[t]{3}{*}{$\chi^{2}$} & \multirow[t]{3}{*}{ P. Values } & \multirow[t]{3}{*}{ Odds Ratio } \\
\hline & Cases & Comparison & & & \\
\hline & No. $(\%)$ & No. $(\%)$ & & & \\
\hline \multicolumn{6}{|c|}{ HCO3 before sessions of $\mathrm{HD}^{* *}$ : } \\
\hline \multicolumn{6}{|r|}{$6600(1877-23209)$} \\
\hline \multirow{2}{*}{ Normal } & & $6(12.0)$ & 60.864 & $<0.001^{*}$ & $66.00(18.77-232.09)$ \\
\hline & $5(10.0)$ & $44(88.0)$ & & & \\
\hline \multicolumn{6}{|c|}{ HCO3 after sessions of HD: } \\
\hline \multicolumn{6}{|l|}{ Low } \\
\hline Normal & $10(20.0)$ & $2(4.0)$ & 6.061 & $0.014^{*}$ & $6.00(1.24-28.98)$ \\
\hline
\end{tabular}




$$
40(80.0) \quad 48(96.0)
$$

\section{HCO3 before the next HD session:}

Low

$\begin{array}{llllll} & 44(88.0) & 14(28.0) & 36.946 & <0.001 * & 18.86(6.58-54.05)\end{array}$

$* \mathrm{P}$ - value $\leq 0.05$ is significant, $* *$ Hemodialysis.

There was a significant difference between study groups by Kt/V. Patients with hypoalbuminemia were 45.77 times more likely to have low Kt/V (Table 3).

Table 3. Comparison of Study Groups by Kt/V

\begin{tabular}{llllll}
\hline \multirow{2}{*}{ Variable } & \multicolumn{2}{l}{ Study groups } & & \\
\cline { 2 - 3 } & Cases & Comparison & $\chi^{2}$ & P. Values & Odds Ratio \\
& No. $(\%)$ & No. $(\%)$ & & \\
\hline Kt $/ \mathbf{V}:$ & & & & \\
Low & $36(72.0)$ & $3(6.0)$ & 45.776 & $<0.001^{*}$ & $40.28(10.76-150.86)$ \\
Normal & $14(28.0)$ & $47(94.0)$ & & & \\
\hline
\end{tabular}

There were significant mean differences of HCO3 before and after sessions of HD, as well as, HCO3 after sessions of HD and HCO3 before the next session (Table 4).

Table 4. Mean differences of serum HCO3 level in cases according to time of hemodialysis sessions

\begin{tabular}{lllll}
\hline Paired & Groups & Mean $\pm \mathbf{S D}^{\infty}$ & Paired t-test & P. value \\
\hline \multirow{2}{*}{ Paired one } & $\mathrm{HCO}_{3}$ before sessions of $\mathrm{HD}^{* *}$ & $13.51 \pm 2.16$ & 21.435 & $<0.001^{*}$ \\
\cline { 2 - 3 } & $\mathrm{HCO}_{3}$ after sessions of HD & $18.86 \pm 2.26$ & 15.476 & $<0.001^{*}$ \\
\hline \multirow{2}{*}{ Paired two } & $\mathrm{HCO}_{3}$ after sessions of HD & $18.86 \pm 2.26$ & $14.15 \pm 2.35$ & \\
\cline { 2 - 4 } & $\mathrm{HCO}_{3}$ before the next session & \multirow{2}{*}{} & & \\
\hline
\end{tabular}

$* \mathrm{P}$ - value $\leq 0.05$ is significant, ${ }^{* *}$ Hemodialysis, ${ }^{\infty}$ Standard deviation.

Logistic regression model showed that patients with acidosis were 102.8 and 7.88 times more likely to have low HCO3 before sessions of HD as well as before the next sessions of HD than comparison group, respectively. Patients were 20.46 and 15.9 times more likely to have two sessions of HD as well as 3 hours for duration of HD than comparison group, respectively (Table 5).

Table 5. Logistic regression model for patients with acidosis and comparison group

\begin{tabular}{|c|c|c|c|c|c|}
\hline \multirow{2}{*}{ Variable } & \multirow{2}{*}{ Wald } & \multirow{2}{*}{ P. value } & \multirow{2}{*}{ Odds Ratio } & \multicolumn{2}{|c|}{ 95\% C.I. for Odds Ratio } \\
\hline & & & & Lower & Upper \\
\hline \multicolumn{6}{|c|}{$\mathrm{HCO}_{3}$ before sessions of $\mathrm{HD}^{\infty}$} \\
\hline \multicolumn{6}{|l|}{ Low** } \\
\hline Normal & 11.255 & $<0.001 *$ & 102.83 & 6.86 & 1540.40 \\
\hline \multicolumn{6}{|c|}{$\mathrm{HCO}_{3}$ after sessions of $\mathrm{HD}$} \\
\hline \multicolumn{6}{|l|}{ Low** } \\
\hline Normal & 0.329 & 0.566 & 2.39 & 0.12 & 47.16 \\
\hline
\end{tabular}




\begin{tabular}{|c|c|c|c|c|c|}
\hline \multicolumn{6}{|c|}{$\mathrm{HCO}_{3}$ before the next $\mathrm{HD}$} \\
\hline \multicolumn{6}{|l|}{ Low** } \\
\hline Normal & 4.168 & $0.041 *$ & 7.88 & 1.08 & 57.28 \\
\hline \multicolumn{6}{|l|}{$\mathrm{Kt} / \mathrm{V}$} \\
\hline \multicolumn{6}{|l|}{ Low } \\
\hline Normal & 1.735 & 0.188 & 0.11 & 0.00 & 2.86 \\
\hline \multicolumn{6}{|l|}{ Session of HD } \\
\hline \multicolumn{6}{|l|}{ Two sessions** } \\
\hline Three sessions & 4.612 & $0.032 *$ & 20.46 & 1.30 & 321.80 \\
\hline \multicolumn{6}{|c|}{ Duration between HD } \\
\hline \multicolumn{6}{|l|}{3 hrs** } \\
\hline 4 hrs & 5.005 & $0.025^{*}$ & 15.92 & 1.40 & 179.85 \\
\hline Age & 0.359 & 0.549 & 1.02 & 0.94 & 1.11 \\
\hline \multicolumn{6}{|l|}{ Gender } \\
\hline \multicolumn{6}{|l|}{ Male** } \\
\hline Female & 0.234 & 0.629 & 1.59 & 0.24 & 10.48 \\
\hline Constant & 5.645 & 0.018 & 0.00 & & \\
\hline
\end{tabular}

$* \mathrm{P}$ - value $\leq 0.05$ is significant, ** Reference group, Hemodialysis.

Mean S. Alb was $(2.34 \pm 0.42) \mathrm{g} / \mathrm{dl},(3.77 \pm 0.22) \mathrm{g} / \mathrm{dl}$ for cases and comparison respectively (Table 6).

Table 6. Mean values of serum $\mathrm{HCO}_{3}$, serum Albumin and $\mathrm{Kt} / \mathrm{V}$ of cases and comparison groups.

\begin{tabular}{|c|c|c|c|c|}
\hline $\begin{array}{l}\mathrm{HCO}_{3} \text { before } \mathrm{HD}^{*} \text { session } \\
\text { meq } / \mathrm{L} \\
\operatorname{Mean} \pm \mathrm{SD}^{* *}\end{array}$ & $\begin{array}{l}\mathrm{HCO}_{3} \text { after } \mathrm{HD} \\
\text { session } \\
\operatorname{Mean} \pm \mathrm{SD}\end{array}$ & $\begin{array}{l}\mathrm{HCO}_{3} \text { before next } \\
\mathrm{HD} \text { session } \\
\text { Mean } \pm \text { SD }\end{array}$ & $\begin{array}{l}\text { Serum Albumin } \\
\text { g/dl } \\
\text { Mean } \pm \text { SD }\end{array}$ & $\begin{array}{l}\text { Kt/V } \\
\text { Mean } \pm \text { SD }\end{array}$ \\
\hline Cases: $13.83 \pm 2.53$ & $19.09 \pm 2.44$ & $14.42 \pm 2.82$ & $2.34 \pm 0.42$ & $1.051 \pm 0.15$ \\
\hline Control: $19.02 \pm 1.71$ & $23.27 \pm 1.84$ & $19.26 \pm 2.19$ & $3.77 \pm 0.22$ & $1.27 \pm 0.22$ \\
\hline
\end{tabular}

* Hemodialysis, ** Standard deviation

\section{Discussion}

In present study, the mean age of cases was $(47.50 \pm 12.25)$ years and the mean age of comparison group was (52.16 \pm 13.58$)$ years. There was no significant mean difference with $P$. value $=0.075$. The study of (Thalacker-Mercer, Johnson, Yarasheski, Carnell, \& Campbell, 2014) showed that albumin synthesis has not been found to change with age. While (Ikuko et al., 2007) showed a significant relation with age from 60 years and above. The maximum age in our study was 65 years old. In this study, there was no significant correlation between $\mathrm{S}$. Alb and gender. Insignificant association between gender and low albumin was also shown in (Tayebeh, \& Ahad, 2011) study.

In present study, there was a highly significant correlation between numbers of sessions of HD (2sessions more than 3 sessions/week) and duration of session (3hours $>4$ hours/ session) with hypoalbuminemia with P. value $=<$ 0.001 . There was $32(64 \%)$ cases with 2 sessions/ week and $18(36 \%)$ cases with 3 sessions/ week while in the comparison group there were only $8(16 \%)$ with 2 sessions and $42(84 \%)$ with 3 sessions per week. The duration of each session was 3 hours in $22(44 \%)$ of cases and 4 hours in $28(56 \%)$ of cases while in the comparison group there were 2(4\%) with 3hour/ session and 48(96\%) with 4 hours per session. Cases were 9 and 18 times more likely to have two sessions of HD for three hours' duration, respectively. The explanation is that patients with 2 sessions/ week and those with 3 hour /session received less dialysis dose and were considered to have inadequate dialysis as compared with those of 3 sessions/ week and 4 hours' duration/ session which limit proper correction of acidosis 
leading to low albumin level as mentioned previously.

Also, inadequate dialysis may lead to uremia, with consequent, anemia, anorexia nausea, vomiting and poor food intake which also leads to low albumin level. (Hemayati, Lesanpezeshki, \& Seifi, 2015) described this relation of hypoalbuminemia with dialysis adequacy and consider it significant correlation. In another study (AL-Saedy. Ali, \& AL-Kahichy Hayder, 2011) it has been also showed that a significant correlation between dialysis adequacy and malnutrition indicated by low albumin and cholesterol.

In present study, there was a significant correlation between S. HCO3 and S. Alb level when measured before dialysis session with P-value $<0.001$, and after dialysis session with $\mathrm{P}$. value $<0.001$ and before next session with $\mathrm{P}$ - value $=0.014$. The number of cases who had low $\mathrm{HCO} 3$ level before dialysis session were $45(90 \%)$ compared to $6(12 \%)$ of comparison group and cases who had normal HCO3 level were 5(10\%) compared to 44(88\%) of comparison group. While after HD session the cases who had normal HCO3 were $40(80 \%)$ compared to $48(96 \%)$ of comparison group and only $10(20 \%)$ of cases had low HCO3 level compared to only $2(4 \%)$ of comparison group. The HCO3 level in cases before next session was normal in 6(12\%) of cases compared to $36(72 \%)$ of comparison group and low in $44(88 \%)$ of cases compared to $14(28 \%)$ of comparison group. The mechanisms by which the acidosis causes hypoalbuminemia were discussed earlier. Our explanations to acidosis in our patient could be due to:

- Inadequate dialysis. Duration of dialysis and numbers of session as mentioned above and vascular access. Despite we didn't intake in our study the number of participant who depend on double lumen but it is still important cause of inefficient dialysis in our patient due to low blood flow and high incidence of inflammation and infection.

- Infection. Increase the infection rate leads to acidosis where most of ESRD patient have low immunity and our patients were not well educated about avoidance of contamination and most of them had poor nutrition.

- Nutritional factors where most of our patients were poorly adherent to diet given by specialist or dialysis unit.

Another study had also shown a significant association of low $\mathrm{HCO} 3$ and albumin level with P- value $=0.019$ (Tayebeh, \& Ahad, 2011). In a previous study; it was concluded that the treatment of acidosis has reduced whole body protein degradation (Chun-Ting, Shih-Hua, Jin-Shuen, \& Yu-Juei, 2013).

In our study, there was a significant difference of study groups by Kt/V. Patients with hypoalbuminemia were 45 times more likely to have low Kt/V with $\mathrm{P}<0.001$. This correlation was focused by many researches. Sridhar, \& Josyula reported that there is a relation between dialysis adequacy and albumin level (Sridhar, \& Josyula 2013).

In present study, we compare in paired one between $\mathrm{HCO} 3$ level before and after HD session where the mean of HCO3 before HD was 13.83 and after HD was 19.09 with $\mathrm{P}$. value $<0.001$. The paired two compared between HCO3 level after HD with mean of 19.09 and before next session which was 14.42 with P. value $<0.001$. This refers that the cases complained from acidosis before HD and this partially was corrected after HD but remained acidosis despite dialysis while before next session of HD.

There would be mild elevation of $\mathrm{HCO} 3$ level before $\mathrm{HD}$ in paired two from $\mathrm{HCO}_{3}$ before $\mathrm{HD}$ in paired one. This occurred because there 18 cases have three sessions/ week. So, the $\mathrm{HCO}_{3}$ before next session in those 18 cases mean midweek session which has better control of acidosis than just $2 /$ week sessions but statically not significant. So, we need in the cases group especially 2 sessions/ week to increase the dialysis $\mathrm{HCO} 3$ to $35-40 \mathrm{mmol} / 1$ and according to case instead of $31.6 \mathrm{mmol} / 1$ to increase post (HD) $\mathrm{HCO}_{3}$ and $\mathrm{HCO}_{3}$ before next session.

In present study, logistic regression model for patients with acidosis and control in ESRD in which the relationship between dependent and independent variables showed that $\mathrm{HCO}_{3}$ level before session of $\mathrm{HD}$ and before next session is statically significant with $\mathrm{P}<0.001$ and $\mathrm{P}=0.04$ respectively, while $\mathrm{HCO} 3$ after HD was statically insignificant, with $\mathrm{P}=0.566$. The number and duration of sessions were statically significant $(\mathrm{P}=0.032, \mathrm{P}=0.025)$ respectively.

In this logistic regression model, $\mathrm{Kt} / \mathrm{V}$ was statically insignificant because it depends on the presence of acidosis. In a study by El-Sheikh, \& El-Ghazaly in 2016, it was concluded that there is a significant relation between serum total protein and the index of hemodialysis adequacy.

\section{Conclusion}

This study shows that patients with metabolic acidosis had a lower serum albumin concentration and there was a significant correlation between numbers, duration and adequacy of hemodialysis sessions and albumin level. We recommend to increase the numbers of dialysis centers in Iraq and adjust the bicarbonate doses in dialysate according to patient's bicarbonate levels. 


\section{Acknowledgements}

The authors declare that there are no competing or potential conflicts of interest. The authors report that there was no funding source for the work that resulted in the article or the preparation of the article. We are grateful for all the medical and paramedical staff in the Iraqi Center for Hemodialysis in Baghdad Teaching Hospital for their work and assistance in completing this study. All authors contributed equally to the study.

\section{Competing Interests Statement}

The authors declare that there are no competing or potential conflicts of interest.

\section{References}

AL- Saedy. A. J., \& AL-Kahichy H. R. (2011). The Current Status of Hemodialysis in Baghdad. Saudi J Kidney Dis Transpl, 22(2), 362-367. Retrieved from http://www.sjkdt.org/text.asp?2011/22/2/362/77648

Azar, A. T., Wahba, K., Mohamed, A. S., \& Massoud, W. A. (2007). Association between Dialysis Dose Improvement and Nutritional Status among Hemodialysis Patients. Am J Nephrol, 27(2), 113-119. https://doi.org/10.1159/000099836.

Byrne, A. L., Bennett, M., Chatterji, R., Symons, R., Pace, N. L., \& Thomas, P. S. (2014). Peripheral venous and arterial blood gas analysis in adults. A systematic review and meta-analysis. Respirology, 19(2), 168-175. https://doi.org/10.1111/resp.12225

Căpuşă, C., Ştefan, G., Stancu, S., Lipan, M., Tsur, L. D., \& Mircescu, G. (2017). Metabolic acidosis of chronic kidney disease and subclinical cardiovascular disease markers. Medicine (Baltimore), 96(47), e8802. https://doi.org/10.1097/MD.0000000000008802

Carrero, J. J, Stenvinkel, P, Cuppari, L, Alp Ikizler, T, Kalantar-Zadeh, K, Kaysen, G., ... Franch, H. A. (2013). Etiology of the protein-energy wasting syndrome in chronic kidney disease: A consensus statement from the International Society of Renal Nutrition and Metabolism (ISRNM). Journal of Renal Nutrition, 23(2), 77-90. https://doi.org/10.1053/jrn.2013.01.001.

Chun-Ting, C., Shih-Hua, L., Jin-Shuen, C., \& Yu-Juei, H. (2013). Muscle wasting in hemodialysis patients: New therapeutic strategies for resolving an old problem. Scientific World Journal. https://doi.org/10.1155/2013/643954.

Daugirdas, J. T, Blake, P. G, \& Ing, T. S. (2015). Handbook of dialysis $\left(5^{\text {th }}\right.$ ed). Wolters Kluwer Health.

El-Sheikh, M., \& El-Ghazaly, G. (2016). Assessment of hemodialysis adequacy in patients with chronic kidney disease in the hemodialysis unit at Tanta University Hospital in Egypt. Indian Journal of Nephrology, 26(6), 398-404. https//doi.org/10.4103/0971-4065.168141.

Gama-Axelsson, T., Heimburger, O., Stenvinkel, P., Bárány, P., Lindholm, B., Qureshi, A.R. (2012). Serum albumin as predictor of nutritional status in patients with ESRD. Clin J Am Soc Nephrol, 7(9), 1446-1453. https://doi.org/10.2215/CJN.10251011.

George, A. K. (1998). Biological Basis of Hypoalbuminemia in ESRD. J AmSoc Nephrol, 9, 2368-2376.

Hemayati, R., Lesanpezeshki, M., \& Seifi, S. (2015). Association of dialysis adequacy with nutritional and inflammatory status in patients with chronic kidney failure. Saudi J Kidney Dis Transpl, 26(6), 1154-60.

Ikuko, G., Hideki, F., Makoto, S., Yoshiyuki, M., Takashi, A. T., \& Hisataka, M. (2007). Relationship between serum albumin level and aging in community-dwelling self-supported elderly population. $J$ Nutr Sci Vitaminol, 53, 37-42.

Kalantar-Zadeh, K. (2016). Moderator's view: Higher serum bicarbonate in dialysis patients is protective. Nephrology Dialysis Transplantation, 31(8), 1231-1234. https//doi.org/10.1093/ndt/gfw258

Kalender, N., \& Tosun, N. (2014). Determination of the relationship between adequacy of dialysis and quality of life and self-care agency. $J$ Clin Nurs, 23(5-6), 820-8. https://doi.org/10.1111/jocn.12208

Kapl, A. A., Halley, S. E., Lance, R.A., \& Graeber, C. W. (1995). Dialysate protein losses with bleach processed polysulphone dialyzers. Kidney Int, 47, 573-578.

Kovesdy, C. P. (2012). Metabolic acidosis and kidney disease: does bicarbonate therapy slow the progression of CKD? Nephrol Dial Transplant, 27(8), 3056-62. https://doi.org/10.1093/ndt/gfs291

Lecker, S. H., Goldberg, A. L., \& Mitch, W. E. (2006). Protein Degradation by the Ubiquitin-Proteasome Pathway in Normal and Disease States. JASN, 17(7), 1807-1819. https://doi.org/10.1681/ASN.2006010038 
Lofberg, E., Wernerman, J., Anderstam, B., \& Bergstrom, J. (1997). Correction of acidosis in dialysis patient's increases branched-chain and total essential amino acid levels in muscle. Clin Nephrol, 48(4), 230-237.

Mirsa, S. (2016). Pro: Higher serum bicarbonate in dialysis patients is protective. Nephrology Dialysis Transplantation, 31(8), 1220-1224. https://doi.org/10.1093/ndt/gfw259

National Kidney Foundation. (2002). NKF-DOQI clinical practice guidelines for chronic kidney disease: Evaluation, classification and stratification: Guideline 4: Estimation of GFR. Am J Kid Dis, 39 (1), 83-86.

National Kidney Foundation. (2015). NFK-DOQI Clinical Practice Guideline for Hemodialysis: 2015 Update. Retrieved from https://www.kidney.org/professionals/guidelines/hemodialysis.

Pathology Harmony Group. (2013). Harmonization of Reference Intervals. Pathology harmony.co.uk. Retrieved from

http://www.acb.org.uk/docs/default-source/committees/scientific/guidelines/acb/pathology-harmony-ii-bioc hemistry.pdf? sfvrsn=2

Pickering, W. P., Price, S. R., Bircher, G., Marinovic, A.C., Mitch, W.E., \& Walls, J. (2002). Nutrition in CAPD: Serum bicarbonate and the ubiquitin proteasome system in muscle. Kidney Int, 61(4), 1286-1292. https://doi.org/:10.1046/j.1523-1755.2002. 00276.x

Pourafshar, N., Pourafshar, S., \& Soleimani, M. (2018). Urine Ammonium, Metabolic Acidosis and Progression of Chronic Kidney Disease. Nephron, 138, 222-228. https://doi.org/10.1159/000481892

Rezende, L.R., Brandão de Souza, P., Modesto Pereira, G. R, \& Lugon, J. R. (2017). Metabolic acidosis in hemodialysis patients: A review. J. Bras. Nefrol, 39(3). https://doi.org/10.5935/0101-2800.20170053

Saeedi, M., Zareie, F., \& Javaheri, F. (2015). The assessment of dialysis adequacy and its related factors among hemodialysis patients, Nurs Deve Health, 6(3), 23-31. Persian.

Sridhar, N. R., \& Josyula, S. (2013). Hypoalbuminemia in hemodialyzed end stage renal disease patients: risk factors and relationships - a 2-year single center study. BMC Nephrol, 14, 242. Published online 2013 Nov 1. https//doi.org/10.1186/1471-2369-14-242.

Tayebeh, S., \& Ahad, G. (2011). The Deleterious Effect of Metabolic Acidosis on Nutritional Status of Hemodialysis Patients. Saudi J Kidney Dis Transpl, 22(6),1149-1154.

Thalacker-Mercer, A. E., Johnson, C. A., Yarasheski, K. E., Carnell, N. S., \& Campbell, W. W. (2007). Nutrient Ingestion, Protein Intake, and Sex, but Not Age, Affect the Albumin Synthesis Rate in Humans. J Nutr, 137(7), 1734-1740.

The Royal College of Pathologists of Australasia [RCPA] Manual. (2015). Retrieved from https://www.rcpa.edu.au/Library/Practising-Pathology/.../A/Acute-phase-reactants

Verove, C., Maisonneuve, N., El Azouzi, A., Boldron, A., \& Azar, R. (2002). Effect of the correction of metabolic acidosis on nutritional status in elderly patients with chronic renal failure. J Ren Nutr, 12(4), 224-228.

Yashpal, P. J., \& Kher, V. (2012). Protein energy wasting in chronic kidney disease: An update with focus on nutritional interventions to improve outcomes. Indian $J$ Endocrinol Metab, 16(2), 246-251. https://doi.org/10.4103/2230-8210.93743

Zha, Y., \& Qian, Q. (2017). Protein Nutrition and Malnutrition in CKD and ESRD. Nutrients, 9, 208. https://doi.org/doi:10.3390/nu9030208

\section{Copyrights}

Copyright for this article is retained by the author(s), with first publication rights granted to the journal.

This is an open-access article distributed under the terms and conditions of the Creative Commons Attribution license (http://creativecommons.org/licenses/by/4.0/). 